International Journal of Instruction e-ISSN: 1308-1470 • www.e-iji.net
July $2018 \bullet$ Vol.11, No.3

p-ISSN: 1694-609X

pp. $511-524$

Received: 25/12/2017

Revision: 27/04/2018

Accepted: 03/05/2018

\title{
The Effect of Project-Based Learning on Student Teacher Self-efficacy and Achievement
}

\author{
Ahmad M. Mahasneh \\ Department of Educational Psychology, Faculty of Educational Sciences, The \\ Hashemite University, Zarqa, Jordan, dahmadmahasneh1975@yahoo.com
}

\author{
Ahmed F. Alwan \\ Department of Educational Psychology, Faculty of Educational Sciences, The \\ Hashemite University, Zarqa, Jordan
}

$\mid$

The study aimed to investigate the effects of project-based learning on student teacher self-efficacy and achievement. This study used a quasi-experimental research design with pre-test and post-test control groups. The study sample consisted of 79 students, 42 in the control group and 37 in the experimental group. To collect data, two instruments were used: Teachers' Sense of Efficacy Scale and Academic Achievement Test. The results showed that statistically significant differences between experimental and control group in self-efficacy and achievement score due to the Project-Based Learning in favor of the experimental group. Based on the results, the researchers recommended adopting the ProjectBased Learning in teaching and learning situations, besides conducting more studies to verify the use of Project -Based Learning versus traditional methods in Arab countries.

Keywords: project-based learning, self-efficacy, teacher self-efficacy, student teacher, achievement

\section{INTRODUCTION}

Constructivist teaching strategies have been introduced into science classes as an attempt to inspire and encourage active student participation in the class. The advantages of these tactics have been asserted by some researchers to include eradicating students' misconceptions, while stimulating more meaningful learning (Liang and Gabel, 2005). Of the many constructivists teaching strategies one of the most popularly used in science classes, according to Filippatou and Kaldi(2010), is projectbased learning. This is supported by Frank and Barzilai(2004) who comment on the rapid increase in the use of this teaching method in Science classrooms, while(Krajcik, Blumenfeld, Marx and Soloway, 1994; Doppelt, 2003) illustrate the benefit to students of their active participation in project-based learning in class, where they are required to

Citation: Mahasneh, A. M., \& Alwan, A. F. (2018). The Effect of Project-Based Learning on Student Teacher Self-efficacy and Achievement. International Journal of Instruction, 11(3), 511-524. https://doi.org/10.12973/iji.2018.11335a 
work collaboratively to solve problems, and then to discuss and reflect on what they have learnt.

This learning system also helps students to improve their practical thinking skills thus enabling them to confidently become active in research and decision-making procedures(Harris, 2002; McGrath, 2002; Solomon, 2003).Project-based learning also develops students' scientific process skills, thus enhancing their scientific problem solving skills and abilities by posing questions, debating ideas, and drawing conclusions(Blumenfed and others, 1991; Westwood, 2006). In addition, project-based learning engenders collaboration between the students and the recognition that as a member of a team, each has responsibilities towards the other members. According to Preuss(2002) through questioning and discussion students broaden their perspective, associating what they are discussing and learning in the classroom with what is happening in the day-to-day world outside. In fact, as illustrated by Blumenfeld and others (1991), students' meta-cognitive skills are improved by project-based learning, enhancing their ability to plan successfully as well as making effective evaluations of their solutions. Finally, Solomon (2003), concludes that due to the fact that projectbased learning generates an equal learning environment, this is a positive contribution to the students' academic achievement.

Following a comprehensive review of the literature however, one concludes that there is a lack of consensus regarding any single definition of project-based learning, although there is general agreement that it is a learner-centered method of instruction (Bas, 2011). As the name suggests, project-based learning is a systematic teaching method in which the prime focus is on learning through projects(Thomas, 2000).

Wurdinger and others(2007), note the following definition of project-based learning: a teaching method whereby students are guided by their teachers through a step-by-step problem solving process, typically: identify the problem; develop a plan; do a 'reality test' on the plan; students will be reflecting on the plan while in the process of designing and completing the project.

As explained by Bell(2010), in a project-based learning classroom the teacher provides a topic for either individual or group learning, to be developed by the students through research or project work and monitored by the teacher.

The active involvement of students through their participation in constructive thought processes is a highly important component in the development of knowledge, providing the student with a self-motivated adaptation phase in the journey of practical experience(Glasersfeld, 1995).Whereas (Blumenfeld and others, 1991; Erdem, 2002; Korkmaz and Kaptan, 2002; Schneider, Krajcik, Marx and Soloway, 2002; Solomon, 2003) consider the project-based learning method as an interdisciplinary technique by which students have the opportunity to examine, evaluate, and discuss solutions to real life problems in the familiar classroom environment, developing their knowledge through the process of designing and constructing their projects. The ethos of this education framework is to train students in logical criticism, self-motivation and responsibility for their learning(Postholm, 2005, 2006; Bell, 2010). 
According to (Glasersfeld, 1995; Singer, Marx, Krajcik and Clay-Chambers, 2000; Colley, 2008), the principal merits of project-based learning are the achievement of knowledge through patience and flexibility (trial-and-error), learning by practical experience, and applying newly-gained knowledge to novel situations and conditions.

For the student teacher using project-based learning in the science classroom, the method focuses on the students' skills in asking questions which stimulate constructive thinking in order to supply an answer, problem formulation, and resolution; another important focus is that of peer assessment and resultant data collection, analysis and reaching conclusions (Krajcik, Czerniak and Berger, 1999; Moje and others, 2001; Wolf and Fraser, 2008).

Korkmaz and Kaptan (2001), set out the framework of rules to be observed by students while directing project work: the study parameters must be clearly defined; each group member has the responsibility to make a contribution; a realistic time period for the study must be determined; the practicality of the project plan must be deliberated.

Bandura (1994), comments on the definition of perceived self-efficacy, noting that as a general concept it defines a person's opinion with respect to his/her competency to achieve expected performance levels, when their success or failure will influence or emotionally impact on their quality of life. Bandura elaborates (1995) on the components of self-efficacy beliefs as being effective, cognitive, and motivational, and therefore effectively controlling the person's feelings, thought processes, selfmotivation, and behavioral traits. Because efficacy perception has a key role in affecting behavior both directly and indirectly, it impacts personal determinants including aspirations and goals, outcome expectations, affective inclinations, and social insecurity and self-doubt.

As illustrated by (Tschannen-Moran, Woolfolk and Hoy, 1998) in their study, the specific concept of teachers' self-efficacy perception is related to both the instructional methods used, and teachers' attitudes towards students. Rather than considering efficacy as a single field, many researchers see it as two distinct dimensions, personal efficacy and general efficacy, the first investigating the perceived impact of personal attitudes and behavior on teaching and learning practice, including the teacher's opinion concerning his/her competence to affect student learning. The second dimension considers the perceived influence of factors that are beyond the teacher's control(Gibson and Dembo, 1984; Woolfolk, Rosoff and Hoy, 1990; Tschannen-Moran and others, 1998).

As elucidated by Bandura (1994, 2002), the concept of teacher efficacy has, in the main, been hypothesized within the personal or self-efficacy viewpoint, normally defined as the teacher's confidence level regarding his/her skill in encouraging and stimulating student learning, the teacher's self-assessment of his/her ability level being determined by the presence of two distinct but interactive expectations: self-efficacy and outcome expectancy. The first refers to the individual's assessment of his/her competence, when given a specific task and context, to accomplish it successfully, whereas the second relates to his/her assessment of the prospective outcome of this successful performance. 
In their study, Ashton and Webb (1986) draw a comparison between the attitudes and attributes of high/low efficacy teachers, concluding that those in the first category exhibit greater organizational ability as well as superior instruction skills, demonstrated in questioning, explaining, providing feedback to students with difficulties, and maintaining task parameters.

Smylie (1989) and Tschannen-Moran and Hoy (2001) provide insightful observations on both groups, commenting that the low efficacy teachers' approach in classroom management is custodial or supervisory rather than humanistic or student oriented; another significant comment is that these teachers devote more time to group work than to giving complete class instruction; these teachers also have difficulty maintaining class discipline calmly and firmly, often responding angrily to misbehavior, and also have a problem with keeping students focused on task. High efficacy teachers on the other hand are more student-oriented, and give greater opportunity for student-student and studentteacher interaction and communication, varying the methods used in order to meet the needs of all the students.

Researchers in many disciplines have investigated efficacy change in project-based learning environments. For example, project-based learning influences student efficacy for academic knowledge in medical education (Papinczak, Young, Groves, and Haynes, 2008), communication and cultural knowledge in foreign language learning (Mills, 2009), and collaboration in software design engineering (Dunlap, 2005). However, researchers have reported mixed results of the direction of the self-efficacy change. Prior research on self-efficacy in a project-based learning environment suggests that the quality of project-based learning experiences impacts students' self-efficacy (Dunlap, 2005). Mills (2009) investigated students' efficacy in a language learning course and found significant increases in student self-efficacy in the areas of "communication, cultures, connections, comparisons, and communities" after participation in a projectbased learning curriculum.

\section{The current study}

As may be seen from the literature review, there have been many studies investigating the effect of project-based learning on science achievement in western countries, but scarcely any in the Arab world in general and Jordan in particular. The present study therefore, offers up-to-date information in the field of project-based learning with these methods of constructivist teaching strategies.

The research questions of the current study are presented as follows:

Question One: what is the effect of project-based learning on student teacher selfefficacy?

Question Two: what is the effect of project-based learning on student teacher achievement?

\section{METHOD}

\section{Participants}

The participants consisted of 79 student teachers at the Faculty of Educational Science, the Hashemite University of Jordan. Of the participants 19 were male(24\%), and 60 
were female $(76 \%)$ were aged 19-22 years. The participants were randomly divided into two groups, the experimental group consisted of 37 (46.8\%) student teachers, and the control group comprised $42(53.2 \%)$ student teachers. All participants were registered for the course "Using Computers in Education" in the second semester of the academic year 2016/2017.

\section{Instruments}

In the current study two tools were used:

Academic Achievement Test: The test consisted of 50 multiple-choice items, each with four alternatives. Each correct answer scored one point, while an incorrect one scored zero. The first draft of the test was submitted to a jury of five experts in the field of computer science, measurement and evaluation. The experts were asked to judge linguistic accuracy and appropriateness for the students. The researchers accepted the jury members' comments and made the required modifications, the researchers kept all 50 items as a final version of academic achievements.

Teachers' Sense of Efficacy Scale: The Teachers' Sense of Efficacy Scale(TSES)(long form)was developed by Tschannen-Moran and Hoy(2001). The TSES consisted of 24 items measuring three subscales for teachers' sense of efficacy. The first subscale tests efficacy of instructional strategies items $(1,2,4,6,9,12,14$, and 22), the second subscale tests efficacy in classroom management items $(7,10,11,17,18,20,23$ and 24) while the third subscale tests efficacy in student participation items $(3,5,8,13,15,16$, 19 and 21). The (TSES) was scored on a nine-point Likert scale ranging from (1) nothing to (9) a great deal. Tschannen-Moran and Woolfolk(2001) calculated the internal consistency of the (TSES) using Cronbach Alpha, as 0.91 for efficacy in instructional strategies, 0.90 for efficacy in classroom management, and 0.87 for efficacy in student engagement. For the purpose of the current study the (TSES) was translated into Arabic and revised by two faculty members to check for language accuracy. The author calculated the internal consistency of the (TSES) using Cronbach alpha as 0.83 for efficacy in instructional strategies constructivist conception, 0.85 efficacy in classroom management and 0.81 for efficacy in student participation.

\section{Project-based learning lesson plan}

Following selection of the study topics, an instruction program was developed by the researcher and the instructor for the "Using Computers in Education" course. Given the specific demands of the course it was vital to its success to furnish the necessary materials and develop appropriate techniques structured around the principles of project-based learning.

In order to ensure parity between the two groups, all members of the experimental and control groups received instruction in the same content of course" Using Computer in Education"; which comprising eight main topics as content outlines: introduction to technology, professional learning network, the flipped classroom (blended learning), mobile learning, e books, virtual classroom, smart board, digital assessment. And for equal duration throughout the period of the study. Each lesson period was 50 minutes and the two groups received equal instruction time throughout the six-week duration of the study. 
While the experimental group was taught the educational software units using the project-based learning method, the control group was taught the same units by traditional classroom methods.

The lesson plans for the educational software units being taught using project-based learning techniques were structured on the following seven steps: Introduction of the topic to students; organization of the groups, project planning; project application; planning the presentation, presentation of the project; project evaluation.

\section{Data collocation and analysis}

The study was conducted in the second semester of the academic year 2016/2017. The participants were told that they would take a test for the purpose of scientific research, and asked to respond accurately and honestly. They were distributed into two halls and then asked to complete the scales individually; all who were asked did so. The test lasted for fifty minutes. After the study had been conducted, the post-test was administered using the same procedures to ensure the equivalence of the experimental and control groups. The achievement test was administered as a pre-test before beginning to teach the students through project- based learning. The experimental group was taught the course for one hour a day for 45 days through project-based learning in their regular classroom. Simultaneously, the control group studied in their classroom using the traditional method of teaching with which the students were familiar. After studying the content, both groups took the post-test. Data were collected and analyzed, using descriptive statistics such as means and standard deviations. ANCOVA was also used to find out whether differences between groups were statistically significant.

\section{FINDINGS}

Based on the data obtained by the student teacher self-efficacy test, the students' mean and standard deviation for pre-test scores for control and experimental groups were as presented in Table 1.

Table 1

Means and standard deviation for the results of student teachers self-efficacy test pretreatment

\begin{tabular}{llllllll}
\hline Variables & Group & $\mathrm{N}$ & Means & S.D & df & t & $\mathrm{p}$ \\
\hline Instructional & Control & 42 & 3.52 & 1.10 & 77 & 0.291 & 0.77 \\
strategies & Experimental & 37 & 3.59 & 1.03 & & & \\
\hline Classroom & Control & 42 & 2.51 & 1.07 & 77 & 1.819 & 0.07 \\
management & Experimental & 37 & 2.16 & 0.58 & & & \\
\hline Student & Control & 42 & 2.54 & 1.43 & 77 & 0.436 & 0.66 \\
engagement & Experimental & 37 & 2.67 & 1.13 & & & \\
\hline Teacher self- & Control & 42 & 2.74 & 0.52 & 77 & 1.333 & 0.18 \\
efficacy & Experimental & 37 & 2.92 & 0.68 & & & \\
\hline
\end{tabular}

The mean score for the control group pre-test was 2.74and the standard deviation was 0.52 , while the mean score of the experimental group was 2.92 and standard deviation was 0.68 . Independent sample $t$-test results showed that there were no significant differences between control and experimental groups $(t=1.333, P=>0.05)$ in the student teacher's self-efficacy score. 


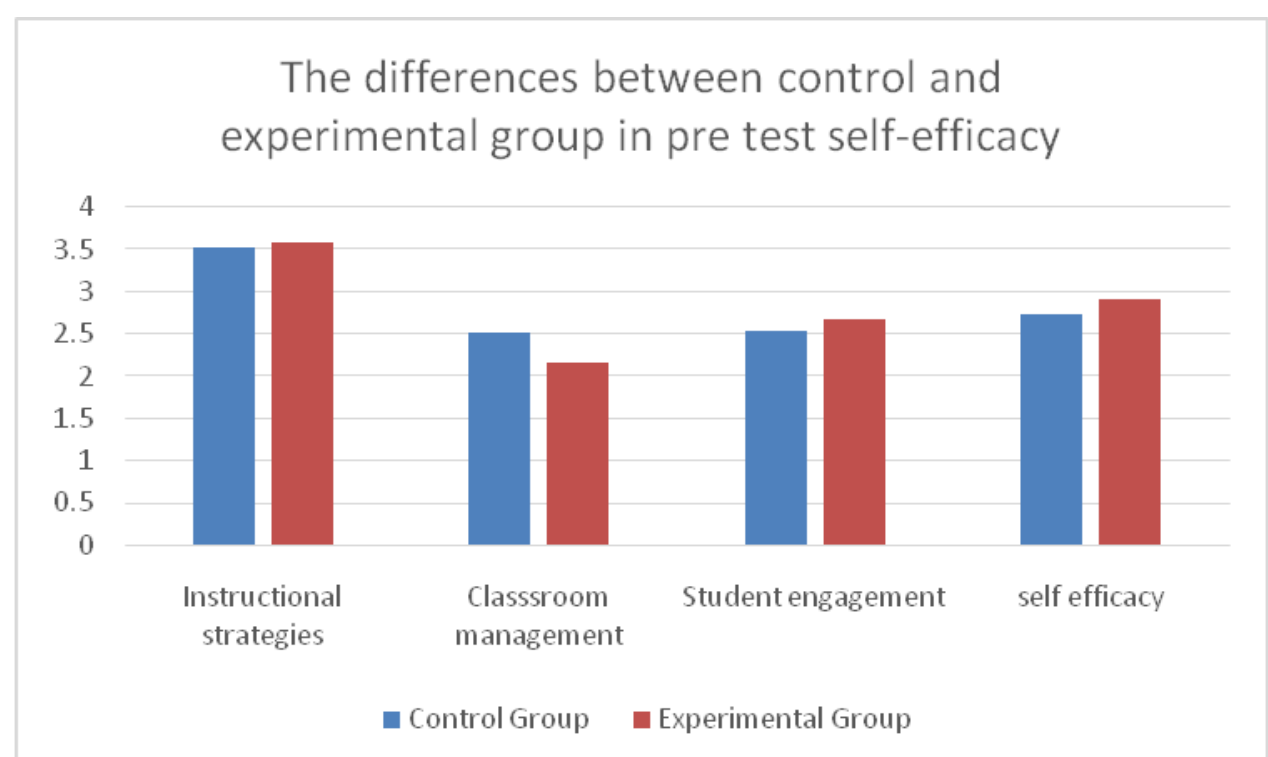

Study Question One: what is the effect of project-based learning on student teachers' self-efficacy?

Means and standard deviations of the student teacher self-efficacy scores on the post-test were calculated, table 2 presents the values.

Table 2

Means and standard deviation for the results of student teachers' self-efficacy test after treatment

\begin{tabular}{|c|c|c|c|c|}
\hline Variables & Group & $\mathrm{N}$ & Means & S.D \\
\hline \multirow{2}{*}{$\begin{array}{l}\text { Instructional } \\
\text { strategies }\end{array}$} & Control & 42 & 3.33 & 1.22 \\
\hline & Experimental & 37 & 4.12 & 0.75 \\
\hline \multirow{2}{*}{$\begin{array}{l}\text { Classroom } \\
\text { management }\end{array}$} & Control & 42 & 2.54 & 1.25 \\
\hline & Experimental & 37 & 3.51 & 1.28 \\
\hline \multirow{2}{*}{$\begin{array}{l}\text { Student } \\
\text { engagement }\end{array}$} & Control & 42 & 2.38 & 1.39 \\
\hline & Experimental & 37 & 3.18 & 1.19 \\
\hline \multirow{2}{*}{$\begin{array}{l}\text { Teacher } \\
\text { efficacy }\end{array}$} & Control & 42 & 2.75 & 0.66 \\
\hline & Experimental & 37 & 3.63 & 0.70 \\
\hline
\end{tabular}

Table 2 shows that there are differences between the control group and the experimental group in the student teacher self-efficacy scores. To determine the significance of the differences, ANCOVA was conducted, table 3 presents the values. 


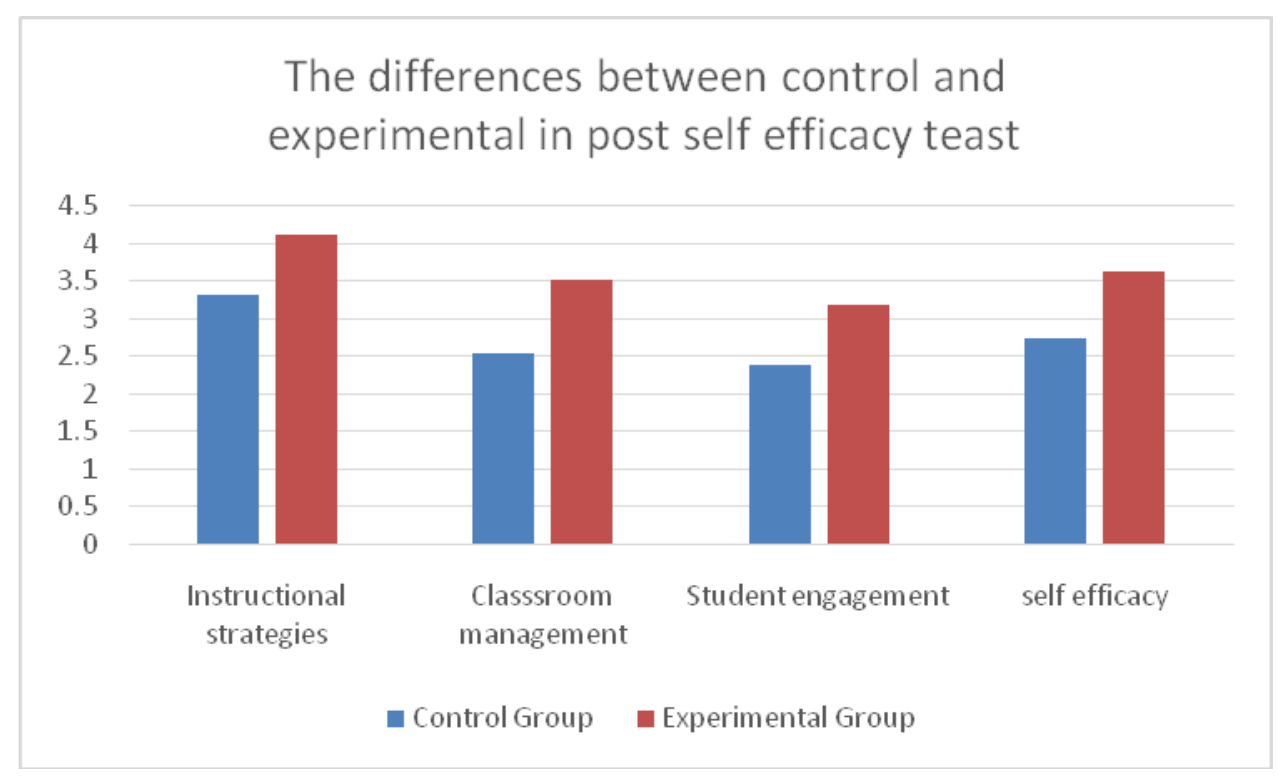

Table 3

ANCOVA determining the significance of the differences between control group and experimental group in student teachers' self-efficacy scores

\begin{tabular}{lllllll}
\hline Source & Sum of squares & df & Means square & F & Sig. & Partial Eta squared \\
\hline Instructional strategies & 18.722 & 1 & 18.722 & 22.627 & 0.00 & .22 \\
Method & 14.213 & 1 & 14.213 & 17.178 & 0.00 & .18 \\
Error & 62.882 & 76 & 0.827 & & & \\
Corrected total & 95.817 & 78 & & & & \\
\hline Classroom management & 28.200 & 1 & 28.200 & 22.454 & 0.00 & .22 \\
Method & 9.715 & 1 & 9.715 & 7.736 & 0.00 & .09 \\
Error & 95.448 & 76 & 1.256 & & & \\
Corrected total & 133.363 & 78 & & & & \\
\hline Student engagement & 33.892 & 1 & 33.892 & 26.368 & 0.00 & .25 \\
Method & 10.832 & 1 & 10.832 & 8.427 & 0.00 & .10 \\
Error & 97.688 & 76 & 1.285 & & & \\
Corrected total & 142.412 & 78 & & & & \\
\hline Teacher self-efficacy & 5.562 & 1 & 5.562 & 13.843 & 0.00 & .15 \\
Method & 12.457 & 1 & 12.457 & 31.004 & 0.00 & .29 \\
Error & 30.536 & 76 & 0.402 & & & \\
Corrected total & 48.555 & 78 & & & & \\
\hline
\end{tabular}

(*Statistical Significance Level of 0.05)

Table 3 shows that there are statistically significant differences in the students teacher self-efficacy post-test between control and experimental groups in all strategies attributed to the project-based learning method in favor of experimental group. More specifically, the instructional strategies explained $22 \%$ the variance in self-efficacy, 
classroom management explained $22 \%$, student engagement explained $25 \%$, and teacher self-efficacy $15 \%$.

Study Question Two: what is the effect of project-based learning on student teachers' achievement?

Based on the data obtained by the students' achievement test, the students' mean and standard deviation for pre-test scores for control and experimental groups were presented in table 4.

Table 4

Means and standard deviation for the results of achievement test pre treatment

\begin{tabular}{llllllll}
\hline Variables & Group & $\mathrm{N}$ & Means & S.D & df & t & p \\
\hline Achievement test & Control & 42 & 10.97 & 5.96 & 77 & 1.376 & .137 \\
& Experimental & 37 & 12.64 & 4.65 & & & \\
\hline
\end{tabular}

Table 4 shows the mean score for the control group pre-test was 10.97 and standard deviation was 5.96, while the mean score of the experimental group was 12.64 and the standard deviation was 4.65. An independent sample t-test results showed that there were no significant differences between control and experimental groups $(t=1.376$, $\mathrm{P}=>0.05)$ in the students' achievement test score.

Means and standard deviations of the student achievement test scores on the post-test were calculated, table 5 presents the values.

Table 5

Means and standard deviation for the results of students' achievement test after treatment

\begin{tabular}{lllll}
\hline Variables & Group & N & Means & S.D \\
\hline Achievement test & Control & 42 & 16.09 & 4.80 \\
& Experimental & 37 & 21.18 & 4.49 \\
\hline
\end{tabular}

Table 5 shows that there are differences between the control group and the experimental group in the student achievement test scores. ANCOVA was conducted to determine the significance of differences. Table 6 presents the values.

Table 6

ANCOVA determining the significance of the differences between control group and experimental group in the students' achievement test scores

\begin{tabular}{lllllll}
\hline Source & Sum of squares & df & Means square & F & Sig. & Partial Eta squared \\
\hline Achievement test & 639.911 & 1 & 639.911 & 47.062 & 0.00 & 0.38 \\
Method & 338.590 & 1 & 338.590 & 24.902 & 0.00 & 0.24 \\
Error & 1033.383 & 62 & 13.597 & & & \\
Corrected Total & 2011.884 & 64 & & & & \\
\hline
\end{tabular}

(*Statistical Significance Level of 0.05)

Table 6 shows that there are statistically significant differences in the achievement test post-test score $(\mathrm{F}=24.902)$ between control and experimental groups in favor of the project-based learning; this means that the method explained $24 \%$ of the variance in achievement. 


\section{DISCUSSION}

The study aimed to investigate the effects of project-based learning on student teacher self-efficacy and achievement. The results showed that there are statistically significant differences in the students teacher self-efficacy post-test between control and experimental groups in all strategies attributed to the project-based learning method in favor of the experimental group. More specifically, the instructional strategies explained $22 \%$ of the variance in self-efficacy, classroom management explained $22 \%$, student engagement explained $25 \%$, and teacher self-efficacy $15 \%$. The results also shows that there are statistically significant differences in the achievement test post-test $\operatorname{score}(F=24.902)$ between control and experimental groups in favor of the project-based learning; this means that the method explained $24 \%$ of the variance in achievement.

Project-based learning requires students to design and complete projects, in the process of which they will be confronted by any number of wide-ranging problems to which they need to find solutions. Problem-solving is a time-consuming process and when necessary to complete an assignment in project-based learning, inevitably demands more of the student's time than passive learning methods, because students typically need to make several attempts before finally reaching a satisfactory completion of their project.

Students learning by this method become both creative and constructive, given the almost unlimited range of diverse projects they may be given, from creating a learning portfolio, constructing a model from a schematic or blueprint, producing a video, or designing a website, the possibilities are endless.

Depending on the educator, he/she may prefer to give the students a particular project, whereas more student-oriented educators allow students to give free rein to their imagination and interests. Students' active involvement in every step leading to the final completion of the project teaches them to organize their thoughts, remain projectcentered, to put forward, argue and defend their points of view, and provides them with the opportunity to engage in activities they find interesting and satisfying, intellectually and creatively(Zoller, 1990).

Several researchers, including Spectori (1990) studying personal efficacy among undergraduate students, found that during the fourth year undergraduate program, which culminated in the student-teachers actually teaching classes, there was a linear increase in their sense of efficacy. This finding is supported by Hoy and Woolfolk (1990) who showed that practicing teachers who had taken extra graduate courses in education had a higher level of personal efficacy. In their study investigating the effect of project-based learning on undergraduate students' self-efficacy beliefs and achievement, Bilgin, Karakuyu and $\mathrm{Ay}(2015)$ found an increase over that reported by those teaching and learning science in the traditional method.

A study conducted by Barak and Dori (2005) on freshman chemistry students found the experimental group learning by the project-based method greatly outperformed the control group taught by traditional textbook methods and chemistry problems. The project-based group was then involved in a project requiring the construction of molecular models, and scored significantly higher on their final exams due to their enhanced understanding of chemical concepts, theories and molecular structures. 
The results of numerous research studies illustrate that students, while in the process of creating and working through problems associated with bringing a project to a successful conclusion, are engaged in their own learning experience, absorbing and practicing important skills such as responsibility and collaboration, time management, and problem solving(Wolff, 2003; Zhang, Peng and Hung, 2009; Hall, Palmer and Bennett, 2012).

Edelson, Gordin and Pea, (1999) and Singer, Tal and Wu, (2003), noted that students who were involved in a scientific project or experiment and who spent time interacting with their classmates developed their understanding of scientific concepts.

In light of current study results, the following relevant suggestions and recommendations are made: (1) Future research to investigate the effect of project-based learning on students' motivation in learning. (2) Future research to investigate the effect of teachers' sense of self-efficacy on students' self-efficacy (3) Future research to investigate the effect of project-based learning on self-regulated learning.

\section{Limitations of the study}

There were some limitations in this study. One limitation was that all participants who studied the course "Using Computers in Education" at the Hashemite University of Jordan in the second semester of the academic year 2016/2017. The second limitation was that all participant were from the undergraduate level at the Hashemite University of Jordan. A third limitation is that all participants in this study voluntarily expressed their intention to participate in the study.

\section{CONCLUSION}

This paper has highlighted the importance of developing project-based learning among Student Teacher Self-efficacy and Achievement. The use of project-based learning enables students teachers to plan their learning easily, work collaboratively with peers and successfully complete their project on time. It is suggested that future work should look into a particular instructional design issue dealing in a bigger project-oriented class for an innovate product development with a high technical expectations.

\section{REFERENCES}

Ashton, P.T., \& Webb, R.B. (1986). Making a difference: Teachers' sense of efficacy and student achievement New York: Longman.

Bandura, A. (1994). Self-efficacy. Encyclopedia of human behavior, 4, 71-81.

Bandura, A. (1995). Exercise of personal and collective efficacy in changing societies. In A. Bandura (Ed.), Self-efficacy in Changing Societies (pp. 1-46). Cambridge University Press.

Bandura, A. (2002). Social cognitive theory in cultural context. Journal of Applied Psychology: An international Review, 51, 269-290.

Barak, M., \& Dori, Y. J. (2005). Enhancing undergraduate students' chemistry understanding through project-based learning in an IT environment. Science Education, 89(1), 117-139. 
Baş, G. (2011). Investigating the effects of project-based learning on students' academic achievement and attitudes towards English lesson. TOJNED: The Online Journal of New Horizons in Education, 1(4), 1-15.

Bell, S. (2010). Project-based learning for the 21st century: Skills for the future. The Clearing House, 83, 39-43. Retrieved November 6, 2014 fromhttp://teacherscollegesj.edu/docs/47-pblforthe21century_1226201292135.pdf].

Blumenfeld, P. C., Soloway, E., Marx, R. W., Krajcik, J. S., Guzdial, M., \& Palincsar, A. (1991). Motivating project-based learning: Sustaining the doing, supporting the learning. Educational psychologist, 26(3-4), 369-398.

Bilgin, I., Karakuyu, Y., \& Ay, Y. (2015). The effect of project- based learning on undergraduate students achievement and self-efficacy beliefs toward science teaching. Eurasia Journal of Mathematics, Science and Technology Education, 11(3), 469-477.

Colley, K. 2008. Project-Based Science. The Science Teacher, 75 (8): 23-28.

Doppelt, Y. (2003). Implementation and assessment of project-based learning in a flexible environment. International Journal of Technology and Design Education, 13,255-272.

Dunlap, J. (2005). Problem-based learning and self-efficacy: How a capstone course prepares students for a profession. Educational Technology Research and Development, 53(1), 65-83.

Edelson, D. C., Gordin, D. N. \& Pea, R. D. (1999). Addressing the challenges of inquiry- based learning through technology and curriculum design. The Journal of the Learning Sciences, 8(3/4), 391-450.

Erdem, M. (2002). The project-based learning. Journal of education faculty, Hacettepe University. 22, 172-179.

Glasersfeld, E.(1995). Radical constructivism: A way of knowing and learning. Washington, DC: The Falmer Press.

Gibson, S., \& Dembo, M. (1984). Teacher efficacy: a construct validation. Journal of Educational Psychology, 76(4), 569-582.

Filippatou, D. \& Kaldi, S. (2010). The effectiveness of project-based learning on pupils with learning difficulties regarding academic performance, group work and motivation. International Journal of Special Education, 25(1), 17-26.

Frank, M. \& Barzilai, A. (2004). Integrating alternative assessment in a project-based learning course for pre-service science and technology teachers. Assessment \&Evaluation in Higher Education, 29(1), 41-61.

Hall, W., Palmer, S., \& Bennett, M. (2012). A longitudinal evaluation of a project-based learning initiative in an engineering undergraduate programme. European Journal of Engineering Education, 37, 155-165. 
Harris, J. (2002). Activity design assessments: an uncharacteristic consensus. Learningand Leading with Technology, 27(7), 42-50.

Hoy, W. K. \& Woolfolk, A. E. (1990). Socialization of student teachers. American Educational Research Journal, 27, 279-300.

Korkmaz, H. \& Kaptan, F. (2001). Fen eğitiminde proje tabanlı öğrenme yaklaşımı [Project-based learning approach in science education. Hacettepe Üniversitesi Ĕ̈itim Fakültesi Dergisi, 20, 193-200.

Korkmaz H. \& Kaptan, F. (2002). The Effects of project-based learning on elementary school students' academic achievement, academic self concepts and study time inscience education, Hacettepe Üniversitesi Eğitim FakültesiDergisi - Hacettepe University Journal of Education, 22, 91-97.

Krajcik, J. S., Blumenfeld, P. C., Marx, R. W., \& Soloway, E. (1994). A collaborativemodel for helping middle grade science teachers learn project-based instruction. The Elementary School Journal, 94, 483-497.

Krajcik, J., Czerniak, C., \& Berger, C.(1999).Teaching Children Science: A ProjectBased Approach. Boston: McGraw-Hill College.

Liang, L. L. \& Gabel, D. L. (2005). Effectiveness of a constructivist approach to science instruction for prospective elementary teachers. International Journal of Science Education, 27(10), 1143-1162.

McGrath, D. (2002). Getting started with project-based learning. Learning and Leading with Technology, 30(3), 42-50.

Mills, N. (2009). A Guide du Routard Simulation: Increasing self-efficacy in the standards through project-based learning. Foreign Language Annals, 42(4), 607-639.

Moje, E. B., Collazo, T., Carrillo, R., \& Marx, R. W. (2001). "Maestro, what is 'quality'?": Language, literacy, and discourse in project-based science. Journal of Research in Science Teaching, 38(4), 469-498.

Papinczak, T., Young, L., Groves, M. \& Haynes, M. (2008). Effects of a meta-cognitive intervention on students' approaches to learning and self-efficacy in a first year medical course. Advances in Health Sciences Education, 13(2), 213-232.

Postholm, M. B. (2005). The teacher shaping and creating dialogues in project work. Teachers and Teaching: Theory and Practices, 11(6), 519-539.

Postholm, M. B. (2006). The teacher's role when pupils work on task using ICT in a project work. Educational Research, 48(2), 155-175.

Preuss, D. A. (2002). Creating a project-based curriculum. Tech Directions, 62(3), 1619.

Schneider, R. M., Krajcik, J., Marx, R. W., \& Soloway, E. (2002). Performance of students in project-based science classrooms on a national measurement of science achievement. Journal of Research in Science Teaching, 39(5), 410-422. 
Singer, J., Marx, R. W., Krajcik, J.S., \& Clay-Chambers, J. (2000). Constructing extended inquiry projects: Curriculum materials for science education reform. Educational Psychologist, 35, 165-178.

Singer, J., Tal, R. T., \& Wu, H.-K. (2003). Using multiple representations to support urban middle school students' understanding of particular nature of matter. School Science and Mathematics, 103, 28-45,

Solomon, G. (2003). Project-based learning: a primer, Technology and Learning, 23(6), 20-30.

Smylie, M. A. (1989). Teachers' views of the effectiveness of sources of learning to teach. Elementary School Journal, 89, 543-558.

Spector, J. E. (1990). Efficacy for teaching in preserves teachers. Paper presented at the annual meeting of the American Educational Research Association, Boston, MA.

Thomas, J. W. (2000). A review of research on project based learning, Retrieved fromhttp://www.k12reform.org/foundation/pbl/research (last accessed 30/08/2015).

Tschannen-Moran, M., \& Hoy, A. W. (2001). Teacher Efficacy: Capturing an elusive construct. Teaching and Teacher Education, 17(7), 783-805.

Tschannen-Moran, M., Woolfolk Hoy, A., \& Hoy, W. (1998). Teacher Efficacy: Its Meaning and Measure. Review of Educational Research, 68(2), 202-248.

Westwood, P. (2006). Teaching and learning difficulties: cross-curricular perspectives, Camber well, Vic: ACER. Press.

Wolf, S. J., Fraser, B. J. (2008). Learning environment, attitudes and achievement among middle-school science students using inquiry-based laboratory activities. Research Science Education, 38, 321-341.

Wolff, S. J. (2003). Design features of the physical learning environment for collaborative, project-based learning at the community college level. St Paul, MN: National Research Center for Career and Technical Education, University of Minnesota.

Woolfolk, A., Rosoff, B., \& Hoy, W. (1990). Teachers' sense of efficacy and their beliefs about managing students. Teaching \& Teacher Education, 6(2),137-148.

Wurdinger, S. D., Haar, J., Hugg, B., \& Bezon, J. (2007). A qualitative study using project based learning in a mainstream middle school. Improving Schools, 10, 150-61.

Zhang, K., Peng, S. W., \& Hung, J. (2009). Online collaborative learning in a projectbased learning environment in Taiwan: A case study on undergraduate students' perspectives. Educational Media International, 46, 123-135.

Zoller, U. (1990). Environmental education and the university: the "problem solvingdecision making act" within a critical system-thinking framework. Higher Education in Europe, 15(4), 5-14. 